\title{
International Migration in Kyrgyzstan: Dynamics and Determinants
}

\author{
Dr. Burulcha Sulaimanova (Kyrgyz-Turkish Manas University, Kyrgyzstan) \\ Daniyar Jasoolov (Public Fund AVEP, Kyrgyzstan)
}

\begin{abstract}
After disintegration of Soviet Union, mass labor migration has been seen in newly independent states. This migration mostly caused by ethnic reasons, while after mid of 1990's the migration predominantly reasoned by economic issues, such as differences in economic growth, wage levels, social conditions and welfare in countries of destination and origin. Due to labor migration in Kyrgyzstan, which is count around the $10 \%$ percent of active population of the country, and high remittance inflow, which is more than $30 \%$ of Gross Domestic Product of Kyrgyzstan, it is important to investigate the factors causing this migration outflow. This paper aims to empirically present the determinants of international migration outflow from Kyrgyzstan, by using nationally representative "Life in Kyrgyzstan 2011" survey.
\end{abstract}

\section{Introduction}

Since 2000 the volume of economic reasoned migration has been rapidly rising in Kyrgyzstan. The number of labor migrants currently working abroad counts around 600 thousand people or about $10 \%$ of the population of Kyrgyzstan (Migration report of Kyrgyzstan, 2015). The migration directed mainly to the two countries: Russian Federation and Kazakhstan. With growing pattern of labor migration, the amount of remittances has grown as well. According to the World Bank since 2003 the money transfer to Kyrgyzstan increased by 28.7 times, from 78.16 million US \$ (4.07\% of GDP) in 2003 to 242.83 million US \$ in 2014. Kyrgyzstan with $30.3 \%$ share is the second largest country with respect to the remittance share to GDP in 2014, after Tajikistan (41.7 \%) (Migration and remittances factbook, 2016). The main remittance sending countries for 2005-2016 periods are the Russian federation (93.6\%) and Kazakhstan 1.4\%.

The large scale of migration outflow and remittances, making domestic economy of Kyrgyzstan dependent on external shocks, related with migration. The immigration law changes in Russian Federation in 2012, 2014 and 2015 have significantly influenced the migration outflow from Kyrgyzstan, consequently impacting the volume of remittance received. Particularly, the denouncement of bilateral agreement between the governments of Kyrgyzstan and Russian Federation, on obtaining the Russian citizenship on preferential terms in 2012, has reduced bymigration outflow by $71.5 \%$. While the economic crisis in Russian Federation and the rapid devaluation of Russian ruble in 2015 has significantly decreased the amount remittances received, thus havedecreased purchasing power of migrant families. These factors show the fact that Kyrgyzstan migration processes, thus demography and economy is dependent on the migrants host country's economic situation and immigration law changes. Here to make short and long term migration policies and strategies coping with migration outflow and its consequences, firstly the empirical assessment of migration determinants is required.

Given these reason this paper aims to firstly make analysis on dynamics of international migration in Kyrgyzstan and secondly empirically investigate the migration determinants and make policy recommendations. The paper is organized as follows: in the second section of the paper the dynamics of international migration and the remittances of Kyrgyzstan is analyzed; then in the third section the empirical literature on the migration determinants reviewed; in the fourth section the methodology of empirical analysis used is described; in the fifth and sixth sections the empirical estimation results and conclusions with recommendations are given.

\section{Migrational Processes in Kyrgyzstan}

Since the independence of Kyrgyzstan, the external migration of the country has faced several structural changes. While, in the literature, there is common division of these changes in to three periods (Мамырканов \& Элебаева, 2013), more detailed divisions can be found as well (Кумскова, 2015). In general, the first period of migration, starts from the the beginning of 1990 and lasts until the middle of the 1990's. In these period mostly Russian speaking population were leaving Kyrgyzstan to return to their homeland. While in the second period (1994-1998) the outflow of migration has decreased but still were mostly reasoned by political reasons, and characterized by motivation of migrants to get a permanent resettlement abroad (Мамырканов \& Элебаева, 2013; Кумскова, 2015). From 1999 a new wave of migration has started, were the movement abroad has temporary character, mostly conducted by labor migrants.

Taking into consideration that this paper aims to investigate the migration processes of Kyrgyzstan from the economics perspective, the external migration of country is divided into two main periods: the first period of migration is seen during the 1991-1998 years, while the second period starts from the 1999 and lasts to our days. The first migration period is mainly based on ethnic or political reasons. As shown in figure 1, the beginning of 
1990's accompanied by mass migration outflow, then this trend is decreasing; while the the number of those coming were declining steadily.

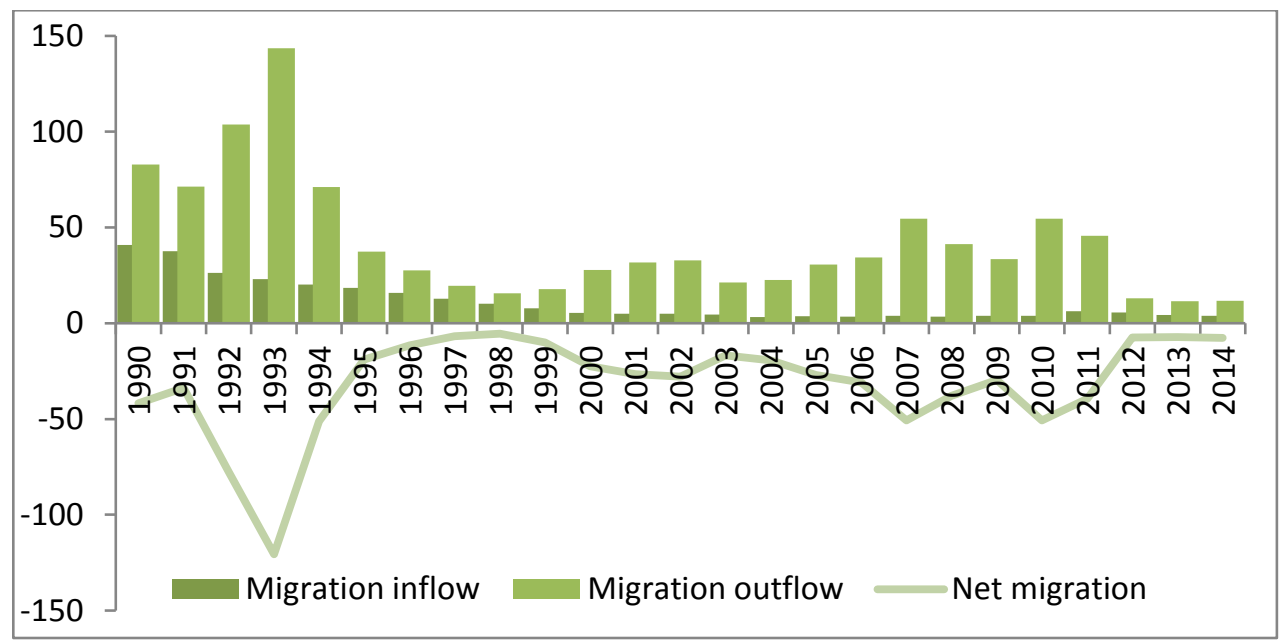

Figure 1. External Migration Dynamics of Kyrgyzstan, (Thousands, People) Source: NSCKR

This mass migration outflow of Russian-speaking population, caused not only by ethnic or historical reasons to return to their homeland, by those who were departed to Kyrgyzstan in 1940's and workers from other nationalities living in Kyrgyzstan; but also were accelerated with political reasons, such as clashes between ethnic groups in Osh in the summer of 1990 (Omarov \& Mahnovskiy, 1998), changes in laws of the state language, and establishment of ethnocentric government (Kumskov, 2015). Mass migration outflow were conducted mostly by family groups going abroad for permanent stay, thus had a negative impact on country's demographic situation.

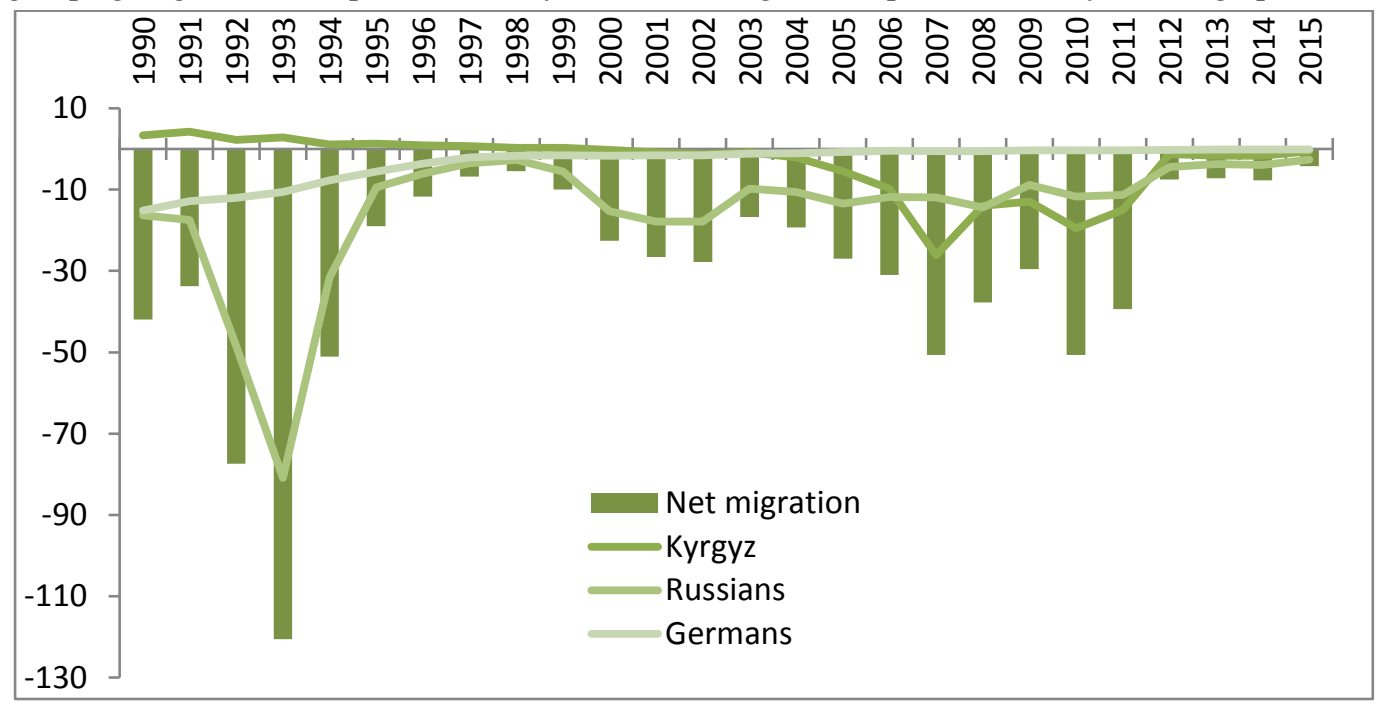

Figure 2. External Migration of the Population by Nationality, (Thousands, People) Source: NSCKR

Investigating the shares of those who have leaved Kyrgyzstan by nationalities, show that the Russian population (1991 - 44.92\%, in 1998. 50.80\%), Germans (1991 - 20.02\%. c. 1998 - 12.34\%) and Uzbeks (1991 - 10.29\%., $1998-7.12 \%$ ) have the biggest shares. During the 1991-1998 periods the destination countries of migrants can be divided into two groups: the CIS countries and the countries outside the CIS countries. Where the $81.7 \%$ of migration were directed to CIS countries, of which 59.56\% were made to Russian Federation; hose going abroad to went to the Russian Federation; the $18.3 \%$ of emigrants went to countries outside the CIS, and mostly to Germany. According to the National Statistics Committee of Kyrgyzstan (NSCKR) the average share of those who have migrated to non CIS countries count around the $22.24 \%$, of which $18.90 \%$ is directed to Germany, showing that those going outside of CIS are mostly Germans. Thus during the period of 1989-1995 the number of Germans living in Kyrgyzstan have ceased by $74.23 \%$ (Omarov \& Mahnovskiy, 1998). 


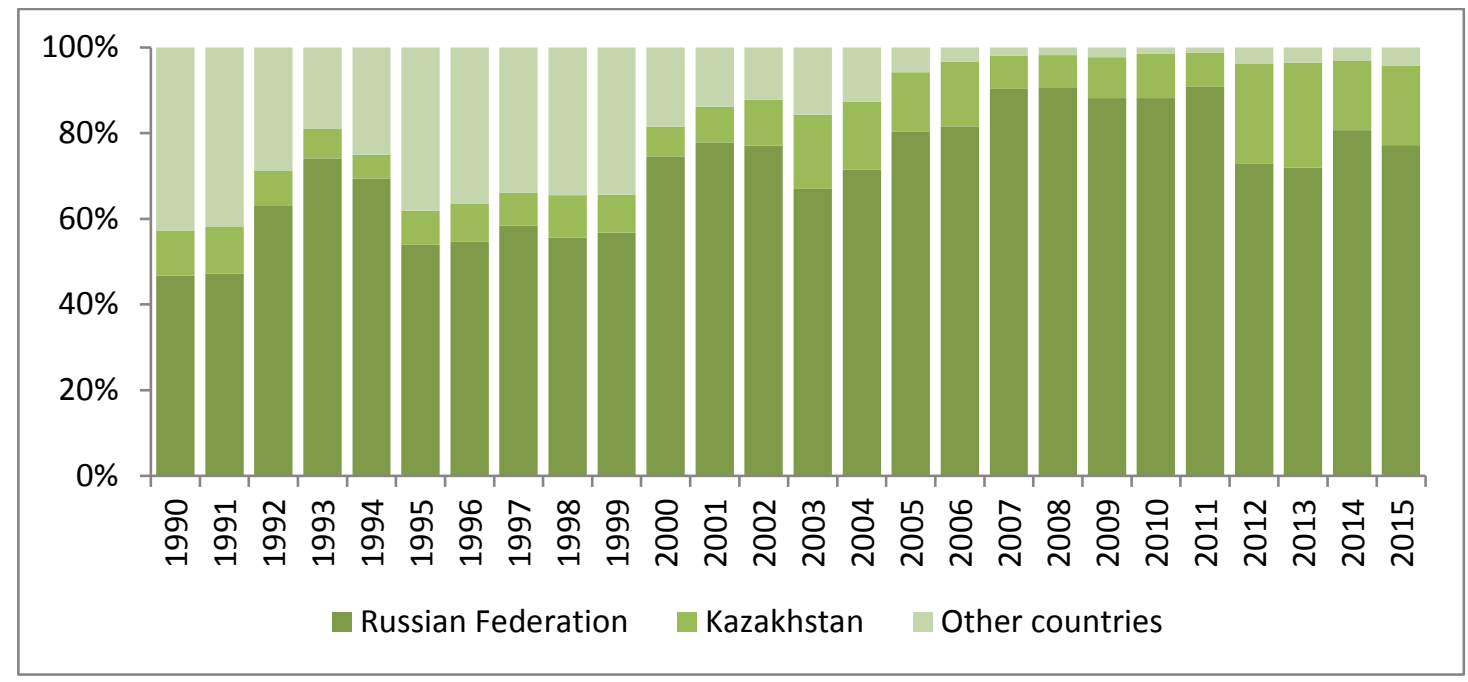

Figure 3. External Migration Shares by Countries. Source: NSCKR

After 2000 the share of those going to non CIS countries sharply decreased. This pattern is explained with the ceased level of ethnic migration stock in the country and this immigration regulations, law changes in the host countries (Mkrtchian \& Sarygulov, 2011). Hence, the immigration policy changes in Germany after 2000 have significantly decreased the number emigrants going to this country (Mkrtchian \& Sarygulov, 2011). While in 1990 's the emigration was directed both to CIS and non CIS countries, after 2000 the emigration was directed to CIS countries, particularly to Russian Federation and Kazakhstan. Furthermore, after 1999 the local population, Kyrgyz has started to actively participate in the migration processes (see Figure2). Hence this migration was economically motivated, specifically migration was conducted by labor migrants to earn more wages, and get better well being abroad. The main features of economically motivated migration are that migration conducted for short or medium term period, migrant going abroad individually leaving their families in the country of origin, sending back to relatives earned money - the remittances, and willing to come back after a while to the country of origin (Sovi, 1977). The distribution of emigrants with respect their gender and ages (see Figure 4.) shows that, in emigration process both men and women are actively participating and the majority of those going abroad are in working ages, which show that emigration after 2000's is done by mostly by active population, who are probably looking for job abroad.

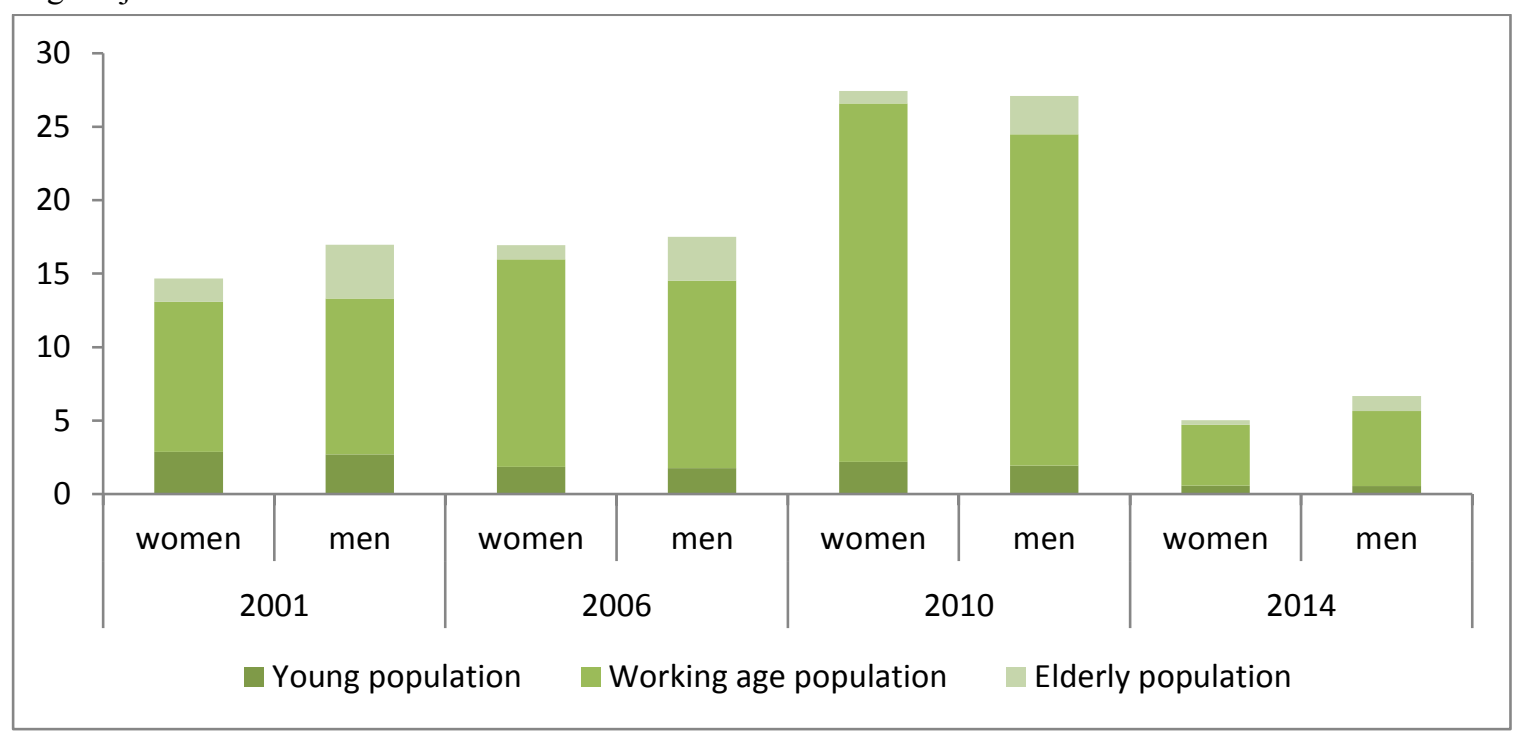

Figure 4. External Migration by Age Categories and Gender, (Thousands, People). Source: NSCKR

After 1999 in the external migration of the Kyrgyzstan the structural change is seen. Specifically, after the financial crisis in the Russian Federation in 1998, which has an economical impact on the Kyrgyzstan, and the the political situation in the south part of the country reasoned the migration outflow from Kyrgyzstan. Particularly, in 1999 the entry of armed groups from Tajikistan into the Batken region of the Kyrgyzstan resulted in internal migration of local population and aftermath emigration to abroad for job search, particularly to Russian Federation (Mkrtchian \& Sarygulov, 2011). 
Investigating the dynamics of external migration shows that there is a sharp decrease of those going abroad after 2012 (see Figure 1). As mentioned above, since 1999, the external migration is motivated by economic reasons and mostly directed to the Russian Federation, the sharp reduction in emigration could be explained with adoption of new immigration law in the Russian Federation. In particular, the denouncement of bilateral agreement between the governments of Kyrgyzstan and Russian Federation, on obtaining the Russian citizenship on preferential terms in 2012 (Demograficheskiy ejegodnik Kyrgyzstana: 2008-2012, 2013) has reduced the number of those going to Russian Federation. This in turn, shows that emigration from Kyrgyzstan is sensitive to law changes in the host countries. Thus, the number of emigrants in 2012, compared to 2011 , has reduced by $71.5 \%$.

However, the statistical data released by National Statistics Committe of Kyrgyz Republic, does not reflect the real situation on external migration of Kyrgyzstan. The methodology of gathering the migration information is based on the counting registration coupons, which are filled by migrants when they are officially changing the permanent place of live. Here we can assume that migrational data released by NSCKR shows general pattern of migration, and the number of those leaving abroad to acquire the other citizenship (in particular case, the Russian Federation citizenship), rather than the actual migration situation in Kyrgyzstan. Thus the labor migration in Kyrgyzstan has temporary and seasonal character and counts around $10 \%$ of active population.

According to experts evaluations the number of labor migrants currently staying abroad counts more than 600 thousand people (more than $10 \%$ of population of Kyrgyzstan). The State Migration Service under the Government of the Kyrgyz Republic announces the number of citizens who are working abroad, as 682 557, these numbers are estimated based on the information gathered from diplomatic missions and consular offices of Kyrgyz Repunlic abroad (Migration report of Kyrgyzstan, 2015). While according to estimations of the Tien-Shan analytical center, every fifth person of active population, or 500 thousand to 700 thousand population has been subjected to labor migration. While the National Statistical Committee of the Kyrgyz Republic, based on surveys of households and labor resources of Kyrgyzstan in 2014, announces the number of migrant workers who are currently staying abroad as 187.4 thousand people. Here, it can be said that, counting the number of labor migrants is difficult and that every organization that is making its counting on migration volume of Kyrgyzstan has different estimation results.

While the volume of external migration of Kyrgyzstan is not definite, based on the experts evaluations can be said to be at high level, and one of it is evident consequences is the remittances sent to Kyrgyzstan. According to Migration and remittances factbook (2016) Kyrgyzstan is the second largest country with respect to the share of remittances in GDP in 2014 with 30.3\% share, after Tajikistan (41.7 \%). According to the World Bank, in 2003 money transfer volume counts 78.16 million US \$ (4.07\% of GDP), while in 2014 this volume increased by 28.7 times and reached 242.83 million US \$ (30.29\% of GDP).

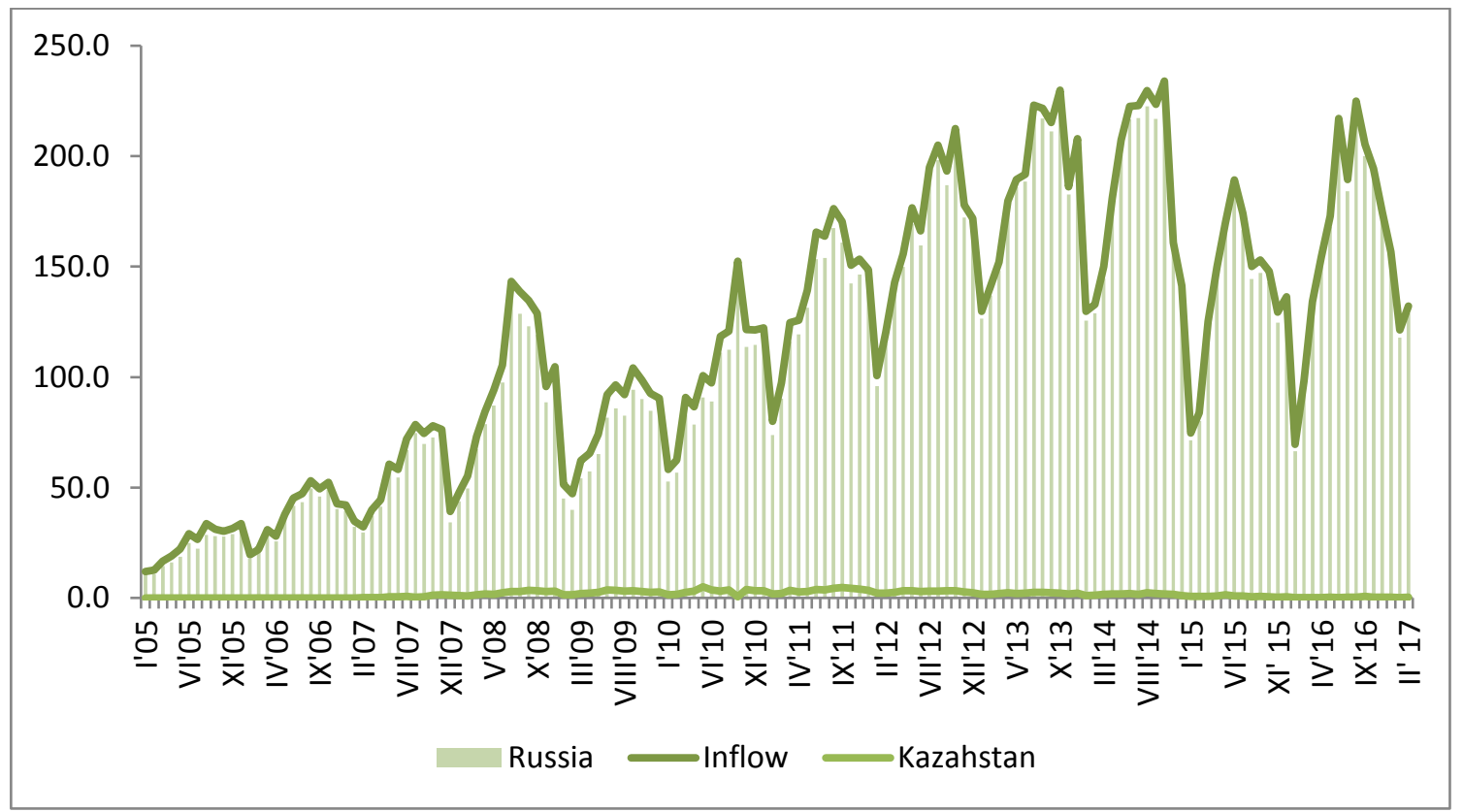

Figure 5. Remittances Made Through the Money Transfer Systems, (in millions of US dollars). Source: NBKR

In the last 15 years the remittances, money transfers have grown rapidly. As it is expected, the main countries sending remittances are Kazakhstan and Russian Federation, in average during the 2005-2016 periods the 93.6\% and $1.4 \%$ of money transfers sent to Kyrgyzstan belongs to these countries, respectively. The remittances display seasonal character, and increases during the summer time. Marat (2009) indicates that most migrants are going to 
the Russian Federation and the Republic of Kazakhstan for seasonal jobs, hence Kyrgyz migrants going abroad in the spring months and send remittance during the employment period, and coming back at winter times.

In purpose of detailed investigation of remittances dynamics, below the seasonal adjusted money transfers are given (see Figure 6). According seasonal adjusted remittances data, there is stationary amount send from Kazakstan, while money transfers send from Russian Federation has dynamic pattern.

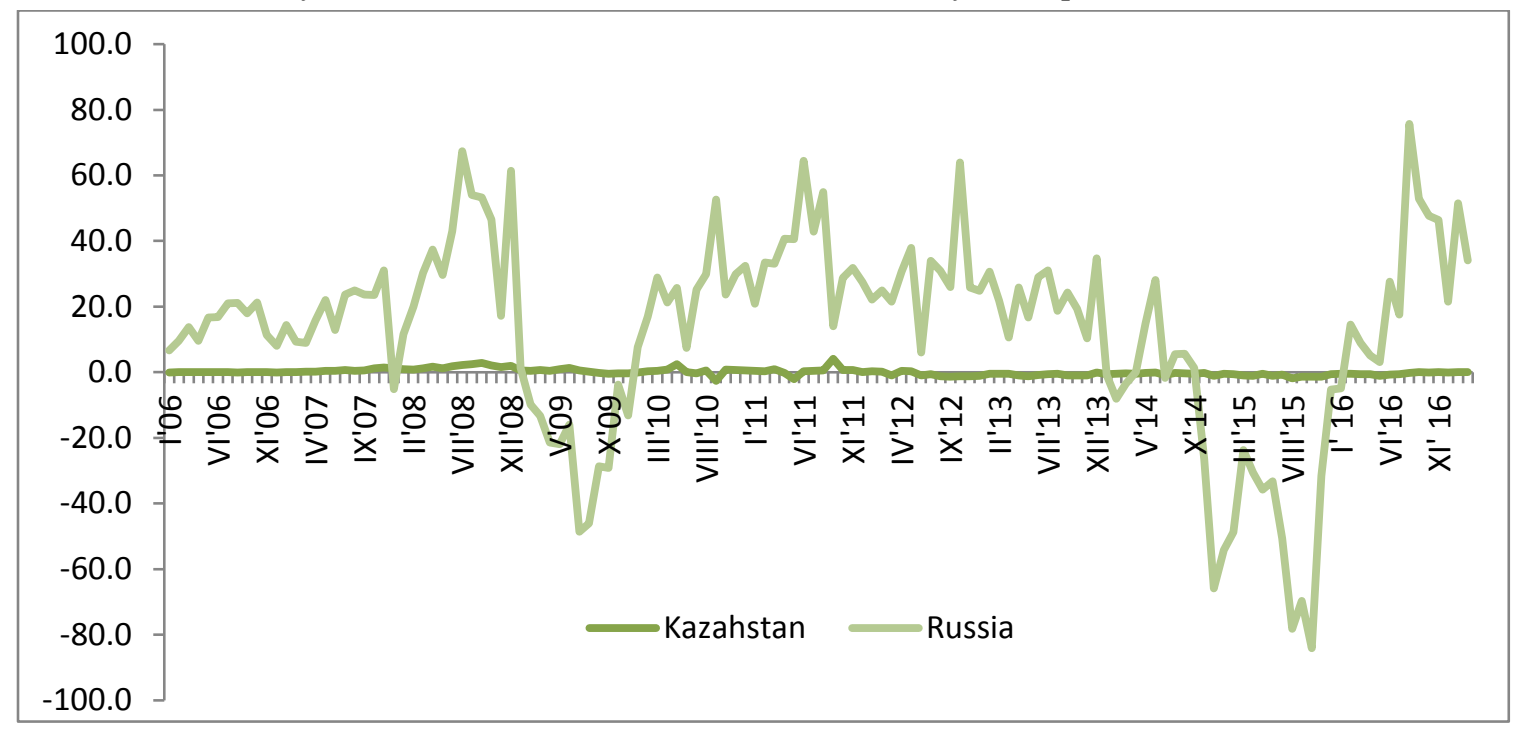

Figure 6. Seasonal Adjusted Remittances, (in millions of US dollars). Source: Calculated Based on NBKR Data

In Figure 6 it is explicitly seen the impact of the Global financial crisis in 2009. However the remittances received from Russian Federation has rapidly recovered. According to estimations of Seyitov (2012) in 2009 the share of remittances with respect to GDP of Kyrgyzstan has not reduced significantly, in 2008 this amount count around $27.1 \%$, while in crisis period, in 2009 it was $20.1 \%$, and in post crisis year, in 2010 it has rapidly recovered and reached $26 \%$ of GDP. In the OSCE and the European Commission report for 2009, despite the global financial crisis of 2009 labor migrants were sending money to their families, showing that money transfers are stable during the financial shocks (Lukashova and Makenbaeva, 2009)

However after 2012 there is reduction in money transfer from Russian Federation is seen. This steady decrease after 2012 could be explained with restrictions introduced to acquire the Russian Federation citizenship in 2012, the adoption of new immigration laws and introducing the "restriction list" ("black list") of those foreigners who are not eligible to enter the Russian Federation for definite period of time. In 2014 the illegal behavior or the number of administrative offenses given to Kyrgyz citizens have for 60\%, from 3853 in 2013 to 6189 in 2014 , resulting in increase of migrants included in restriction list. Hence, after introducing ths list, the number of Kyrgyz citizens, whose enter to Russian Federation were restricted, prohibited have increased drastically, from 7000 in 2013 to 60000 in 2014 .

The sharp decline in remittances at the end of 2014 and during the 2015 is explained with economic crisis seen in Russian Federation, mostly with the situation in foreign exchange market in Russia and the new immigration laws established in beginning of 2015. Due to the reason that official data in Kyrgyzstan on remittances received given in US dollar, it is seems that remittances have shrink very much, while taking into consider the fact that most labor migrants earning and sending transfers in Russian rubles (Muktarbek kyzy, et.al., 2015), the impact of economic crisis on amount of remittances sent is not so much and it is mostly reflecting Russian ruble devaluation. Karymshakov and Sulaimanova (2015) estimates that remittances sent to Kyrgyzstan during the economic crisis in 2015 in Russian rubles has not decreased. However the rapid devaluation of Russian ruble has significantly decreased the purchasing power of migrant families, showing that remittances very sensitive to the migrant host country's economic situation and immigration law changes.

In general in the years of independence, the migration process of Kyrgyzstan can be divided in two main periods: in the first period migration was motivated with non-economic reasons, while in the second period it was economically reasoned and unidirected to CIS countries, namely to Russian Federation and Kazakhstan. The number of those going abroad to work is reaching $10 \%$ of population, and has significant money transfers to Kyrgyzstan, which is very sensitive on the immigration law changes and economic situation in the host countries of migrants. 


\section{Literature Review}

There is large empirical literature on estimating and evaluating the macro and micro level determinants of migration. For instance, Olowa and Awoyemi (2012) have studies Nigerian migration by using multinomial logit model with 2004 survey data and have found that education level is very important factor, thus those having tertiary education are more likely to emigrate abroad, while other more likely to migrate within the country. The same result was found by Chiquiar and Hanson (2005), Uysal and Aktash (2011), .

Ambrosini and Peri (2012) have found that there is significant impact of household characteristics on migration decision of individual, here it is important to mention that the existence migration network is very strong migration causing factor.

Brogerhoff and $\mathrm{Eu}$ (1993) have showed that there is gender specific migration determinants exist, thus women are more likely to take decision on migration with respect to their education level, birth amount, ethnicity, marital status and ages. Yang and Guo have found the same results; hence they show that men more likely to decide to migrate based on the characteristics of the host country or region; while women are likely to migrate withrespect to their individual characteristics.

The main factors causing the labor migration is the wage, income and GDP differentials between regions and countries (Carlos, 2002; Cebula 2005; Guan and McElroy, 2012; Constantinou and Diamentides, 1985; Balderas and Greenwood, 2009; Mayda, 2010; Etzo, 2008; Lewer and Van der Berg, 2008). While the other important factors of deciding to the particular place is the social services given to migrants in host country (Carlos, 2002).

The other important factors at macro level are the cultural similarities between host and origin countries of migrants, demographic characteristics of these countries and geographical distances (Mayda, 2010; Lewer and Van der Berg, 2008). Thus increase of number of population in country of origin leads to migration outflow from this country (Uysal and Aktash, 2011; Carlos, 2002; Kim and Cohen, 2010). Due to the reason that most countries of giving migration are developing countries, the agricultural sector is very important, thus the unexpected agricultural shocks in these countries may cause migration outflow (del Ray Poveda, 1995; Uysal and Aktash, 2011).

One of the other important macro determinants of migration is the migrational law changes in the host countries. Migrants more likely to migrate to the regions were migration laws relaxed (Carlos, 2002; Constantinou and Diamentides, 1985). However Lottum and Marks (2012) have found that migrants are more likely to migrate to economically developed regions rather than to the regions were the immigration laws are not very strict.

The determinants of migrational process in Kyrgyzstan is investigated broadly, hence there is not much empirically investigation is made. One of the first papers examining the migration factors from Kyrgyzstan to USA is made by Sulaimanova, by using survey analysis methods. Agadjanian and et.al. (2006) has found that with increase of ages, and the individuals from other nationalities (not Kyrgyz) more likely to emigrate abroad. Here it is important to mentionthat this paper was written based on the data belonging to beginning of 2000's, where the labor migration has not spread widely, and migration were by those who were planning to go abroad for permanent stay. Thus the empirical results suggest that individual and household characteristics are not important at taking decision decision to migrate, but the presence of relative abroad is very important factor to cause migration.

Lukashova and Makenbaeva (2009) have showed that the main reason for going to Russian Federation is the wage level differentials between countries and unemployment in Kyrgyzstan. According to the macro and micro level of estimation made Eurasian Development Bank's Centre for Integrations studies in 2013, the main factors causing migration outflows are economic ones, namely the low level of Gross Domestic Product per capita in Kyrgyzstan.

Tary and Sulaimanova (2014) has empirically shown that the macro economic migration determinants are GDP, the value added per worker in the agricultural sector in Kyrgyzstan and devaluation national currency with respect to the US dollar. The same results were found by Sulaimanova and Bostan (2014) and the demographic factors were emphasized as well.

Karymshakov and et.al. (2014) have empirically shown that individuals with secondary education and having large households are likely to migrate, while individuals with households that have stable wage incomes and social insurance less likely to migrate.

In general, surveying the empirical literature, particular for Kyrgyzstan case as well, suggest that migration is mostly caused by economical reasons, wage and income level differences and the high level of unemployment rate.

\section{Methodology and Data}

In order to investigate the determinants of international migration the "Life in Kyrgyzstan in 2011" (LIK) survey is used. This survey was conducted within the research project "Economic Transformation, Household behavior and Well-being in Central Asia: The case of Kyrgyzstan" by German Institute for Economic Research DIW Berlin 
with collaboration of Center for Social and Economic Research, CASE-Kyrgyzstan. This survey is nationaly representative and includes 3000 households, 8066 individuals and 40 communities sample. The survey has detailed information on the demographics of the population, health, level of education, labor market participation, standard of living of households and other information on a wide range of topics. Moreover, LIK survey has detailed information on labor migration and remittances, in particular the number of migrants, their destinations, places of work, amount of remittances received along with their expenditure items.

The determinants of migration will be estimated in two ways. Firstly, the migration variables will be taken as a continuous variable and will be estimated with Multiple regression and Tobit models. While in the second method the migration process will be treated as binary variable, and the probability of migration will be estimated with Logit and Probit models.

The first, and simplest analysis is using the number of migrants in the household $\left(w_{i}\right)$ and regressing with the set of explanatory variables $\left(x_{k i}\right)$. Multiple regression is estimated with the least squares and formally model can be given as follows:

$$
w_{i}=\beta_{0}+\beta_{1} x_{1 i}+\beta_{2} x_{2 i}+\cdots+\beta_{k} x_{k i}+u_{i}
$$

Due to the zero inflated nature of the continuous dependent variables, in other words, due to the reason that household that does not have migrants entering to the model estimation as well, using the Tobit model, for means of comparison, will be appropriate. Formally, model is given below (Wooldridge, 2002):

$$
\begin{gathered}
w_{i}^{*}=\beta_{0}+x \beta+\varepsilon_{i} \\
x \beta=\beta_{1} x_{1}+\cdots+\beta_{k} x_{k} \\
u \mid x \sim \operatorname{Normal}\left(0, \sigma^{2}\right) \\
w=\max \left(0, w^{*}\right)
\end{gathered}
$$

where $w_{i}^{*}$ is latent dependent variable and the equation (2) is estimated with Maximum likelihood method.

In the second way of investigating factors of migration the Logit and Probit models are used, where the migration process treated as binary response outcome. These models estimated with Maximum likelihood and the formula of these models is given below (Wooldridge, 2002: 530):

$$
\begin{gathered}
P(y=1 \mid x)=\quad G\left(\beta_{0}+\beta_{1} x_{1}+\cdots+\beta_{k} x_{k}\right)=G\left(\beta_{0}+x \beta\right) \\
x \beta=\beta_{1} x_{1}+\cdots+\beta_{k} x_{k} \\
0<G(z)<1
\end{gathered}
$$

where in the Logit model the function $\mathrm{G}$ is the logistic function and is cumulative distribution function for a standard logistic random variable.

$$
G(z)=\exp (z) /[1+\exp (z)]=\Lambda(z)
$$

In the probit models the function $\mathrm{G}$ is given as standard normal cumulative distribution function (cdf), and expressed as follows:

$$
\begin{aligned}
& G(z)=\Phi(z) \equiv \int_{-\infty}^{z} \phi(v) d v \\
& \phi(z)=(2 \pi)^{-1 / 2} \exp \left(-z^{2} / 2\right)
\end{aligned}
$$

The effect of explanatory variables on migration probability, due to the nonlinear nature of $\mathrm{G}$ function, is calculated as partial effects.

$$
\begin{gathered}
\frac{\partial p(x)}{\partial x_{i}}=g\left(\beta_{0}+x \boldsymbol{\beta}\right) \beta_{i} \\
g(z) \equiv \frac{\mathrm{d} G}{\mathrm{~d} z}(z)
\end{gathered}
$$

The dependent variable $y_{i}$ is the binary response variable, where it takes value 1 if the household has any migrant, and value 0 if the household do not have migrant. The $x_{i}$ refers to a set of independent variables on individual, household and community level. The set of individual variables includes demographic and educational characteristics of individual, in the household level variables the the composition of household and location is given, while in community level variables the settlement features of the region is given. 


\section{Estimation Results}

\begin{tabular}{|c|c|c|c|c|}
\hline & \multicolumn{2}{|c|}{ Migration amount } & \multicolumn{2}{|c|}{ Migration status } \\
\hline & \multicolumn{2}{|c|}{ Coefficient estimates } & \multicolumn{2}{|c|}{ Margin estimates } \\
\hline & OLS & Tobit & Probit & Logit \\
\hline \multicolumn{5}{|l|}{ Individual characteristics: } \\
\hline Age & $\begin{array}{c}-0.0038 \\
(0.0038)\end{array}$ & $\begin{array}{l}-0.0223 \\
(0.0268)\end{array}$ & -0.0014 & -0.0008 \\
\hline Age squared & $\begin{array}{r}0.00009 * * \\
(0.00004)\end{array}$ & $\begin{array}{l}0.0005^{*} \\
(0.0003)\end{array}$ & 0.00003 & 0.00002 \\
\hline Gender $($ male $=1)$ & $\begin{array}{c}-0.0273 * * \\
(0.0127)\end{array}$ & $\begin{array}{l}-0.2664 * * \\
(0.0926)\end{array}$ & $-0.0184 * * *$ & $-0.0161 * * *$ \\
\hline Marital status (married=1) & $\begin{array}{c}0.0079 \\
(0.0211)\end{array}$ & $\begin{array}{l}-0.0177 \\
(0.1559)\end{array}$ & 0.0007 & 0.0024 \\
\hline Nationaility (kyrgyz=1) & $\begin{array}{c}0.0767 * * * \\
(0.0140)\end{array}$ & $\begin{array}{c}0.5479 * * * \\
(0.1048)\end{array}$ & $0.0281 * * *$ & $0.0220 * * *$ \\
\hline \multicolumn{5}{|c|}{ Education level (reference: basic and secondary education): } \\
\hline - $\quad$ Technical education & $\begin{array}{c}0.0454 * * \\
(0.0175)\end{array}$ & $\begin{array}{c}0.3276^{* *} \\
(0.1265)\end{array}$ & $0.0213 * *$ & $0.0209 * *$ \\
\hline - Tertiary education & $\begin{array}{l}-0.0135 \\
(0.0180)\end{array}$ & $\begin{array}{l}-0.1368 \\
(0.1374)\end{array}$ & -0.0066 & -0.0056 \\
\hline \multicolumn{5}{|l|}{ Household characteristics: } \\
\hline Household head gender (women=1) & $\begin{array}{c}0.0568 * * * \\
(0.0156)\end{array}$ & $\begin{array}{c}0.3631 * * \\
(0.1189)\end{array}$ & $0.0229 * * *$ & $0.0170^{* *}$ \\
\hline Household size & $\begin{array}{c}0.0545 * * * \\
(0.0061)\end{array}$ & $\begin{array}{c}0.3239 * * * \\
(0.0412)\end{array}$ & $0.0171 * * *$ & $0.0145^{* * *}$ \\
\hline Children (0-5 ages) & $\begin{array}{c}-0.0853 * * * \\
(0.0105)\end{array}$ & $\begin{array}{c}-0.5968 * * * \\
(0.0762)\end{array}$ & $-0.0355 * * *$ & $-0.0307 * * *$ \\
\hline Children (6-17 ages) & $\begin{array}{c}-0.0477 * * * \\
(0.0079)\end{array}$ & $\begin{array}{c}-0.2712 * * * \\
(0.0547)\end{array}$ & $-0.0149 * * *$ & $-0.0124 * * *$ \\
\hline Males (15-65 ages) & $\begin{array}{c}0.0698 * * * \\
(0.0095)\end{array}$ & $\begin{array}{c}0.4184 * * * \\
(0.0611)\end{array}$ & $0.0292 * * *$ & $0.0239 * * *$ \\
\hline Non-wage income & $\begin{array}{c}-0.0252 * * * \\
(0.0040)\end{array}$ & $\begin{array}{c}-0.1836 * * * \\
(0.0296)\end{array}$ & $-0.0120 * * *$ & $-0.0096 * * *$ \\
\hline Residence (rural=1) & $\begin{array}{c}-0.1004 * * * \\
(0.0172)\end{array}$ & $\begin{array}{c}-0.5777 * * * \\
(0.1233)\end{array}$ & $-0.0330 * * *$ & $-0.0277 * * *$ \\
\hline \multicolumn{5}{|l|}{ Regions (reference: Central region) } \\
\hline - North & $\begin{array}{c}0.0034 \\
(0.0231)\end{array}$ & $\begin{array}{c}0.2740 \\
(0.2151)\end{array}$ & 0.0130 & 0.0133 \\
\hline - $\quad$ South & $\begin{array}{c}0.0127 \\
(0.0197)\end{array}$ & $\begin{array}{l}0.8948 * * * \\
(0.1602)\end{array}$ & $0.0474 * * *$ & $0.0517 * * *$ \\
\hline \multicolumn{5}{|l|}{ Community characteristics: } \\
\hline Presence of major factory, employer & $\begin{array}{c}-0.0636 * * * \\
(0.0172)\end{array}$ & $\begin{array}{c}-0.4111^{* *} \\
(0.1289)\end{array}$ & $-0.0300 * * *$ & $-0.0254 * * *$ \\
\hline Migration network & $\begin{array}{l}0.0360 * * * \\
(0.0021)\end{array}$ & $\begin{array}{l}0.1704 * * * \\
(0.0125)\end{array}$ & $0.0120 * * *$ & $0.0092 * * *$ \\
\hline Distance to the country border & $\begin{array}{l}-0.0080 \\
(0.0054)\end{array}$ & $\begin{array}{l}-0.1261 * * * \\
(0.0373)\end{array}$ & $-0.0071 * * *$ & $-0.0060 * * *$ \\
\hline Constant & $\begin{array}{c}0.0716 \\
(0.0805) \\
\end{array}$ & $\begin{array}{c}-3.4716^{* * *} \\
(0.5897) \\
\end{array}$ & & \\
\hline Number of observation & 7341 & 7341 & 7341 & 7341 \\
\hline $\mathrm{F}-$ stat. & $83.41 * * *$ & - & - & - \\
\hline $\mathrm{R} 2$ & 0.1780 & 0.1759 & 0.2462 & 0.2485 \\
\hline LR $\chi^{2}$ & - & $1395.5^{* * *}$ & $1344.9 * * *$ & $1357.5 * * *$ \\
\hline Log likelihood & - & -3268.93 & -2058.8 & -2052.6 \\
\hline
\end{tabular}

Table 1. Estimation Results (Coefficient and Marginal Effect Estimates)

Table 1 reports the determinants of international migration in Kyrgyzstan with four models; multiple regression, Tobit, Logit and Probit models. According to empirical estimation results the model estimated with ordinary least 
squares has different results on significance of migration determinants, showing that disregarding the nature of censored data of dependent variable will lead to biased estimation, given this reason the Tobit model will be evaluated. Hence the results for probability for being migrating, estimated by Logit and Probit models, justify the significance of variables impacting the migration.

Examining the significant individual level migration determinants show that in Kyrgyzstan in migration processes the women and Kyrgyz are more actively participating, and the educational level of individuals has statistical significant impact. However the tertiary education is not significant at impacting the migration decision of the individual. The individuals, who have technical education more likely to migrate than those having basic or secondary education, this could be explained with the demand for unskilled migrant labor in Russian Federation. Hence we can say that more skilled or educated people are going abroad for Kyrgyzstan case.

The age of migrants is not significant at impacting the migration decision of individual. Interestingly this result is not in line with the literature, where migrants prone to migrate until the definite ages then the migration propensity fall (Ambrosini \& Peri, 2012). This feature of the migration in Kyrgyzstan could be explained with fact that in total decision to make migration the age factor is not significant in general. Hence the same could be said for the marital status of migrants as well.

There are statistically significant household level factors impacting the migration decision of individual. Thus the compositional and residential characteristics of the household are very important determinants of migration. The factors causing migration are the gender of household head, where individuals from female headed households more likely to migrate, with the increase of the size of the household the number of migrants going abroad is increasing as well; particularly with the increase of number of males in the working ages in the household increases the probability of migration from these households; and most migrants come from South region of Kyrgyzstan. While the increase of number of children in the household and the increases of non-wage income are decreasing the migration probability of the individual. Here the household income and welfare impact has expected impact. Thus individuals with stable income in the country of origin are less likely to migrate to work abroad (Ambrosini \& Peri, 2012).

The migration factor that has unexpected sign is the residence of individual in the rural areas. However in case of Kyrgyzstan, where the large scale of internal migration exists, this results could be explained with fact that migrants before going abroad more prone to migrate to bigger cities in Kyrgyzstan and then go abroad.

In addition to the individual and household factors, this study has examined the impact of community features on the migration processes. In line with the literature we have found that community's settled in the areas close to the country border more likely to have migrants (Yang \& Guo, 1999; Ambrosini \& Peri, 2012). However this is not explaining the mass migration to Russian Federation, thus Kyrgyzstan do not have border with this country. The impact of this variable more likely to explain the fact that communities settled near the country border are in remote areas and less developed, which causes the migration outflow from this areas.

The presence of major factor or the employer in the community is significantly reducing the probability of individual to migrate. In particular this result shows the fact that individuals facing problems finding the work in their communities and for this reason have to leave it. While the presence of migration network in this community increases the probability of migration.

\section{Conclusion}

Kyrgyzstan is demographically young country, with large share of labor migration outflow. During the 19912017 periods the two main structural changes in the migration processes are seen. The first period belongs to the 1991-1998 period, and migration has been caused mostly by non-economical reasons, such as ethnic migration, migration for political reasons etc. While after 1999 the active labor migration has started and continues to nowadays. The main countries of attraction of labor migrants are Russian Federation and Kazakhstan. Hence the major part of labor migrants from Kyrgyzstan is going to Russian Federation. However exact number of labor migrants currently working abroad is not known, and evaluated by experts and migrations institutions around 600 thousand people or about $10 \%$ of the population of Kyrgyzstan. With growing pattern of labor migration since 2000, the amount of remittances has grown as well. According to the World Bank since 2003 the money transfer to Kyrgyzstan increased by 28.7 times, from 78.16 million US \$ (4.07\% of GDP) in 2003 to 242.83 million US \$ in 2014 . Kyrgyzstan with $30.3 \%$ share is the second largest country with respect to the remittance share to GDP in 2014, after Tajikistan (41.7\%) (Migration and remittances factbook, 2016).

Since large scale of migration outflow from Kyrgyzstan and remittances received makes domestic economy dependent on external shocks related with migration, it is aimed in this paper to empirically investigate the labor migration determinants, which are could be used for migration policy strategies. In order to investigate the determinants of international migration the "Life in Kyrgyzstan in 2011" (LIK) survey is used. This survey was conducted within the research project "Economic Transformation, Household behavior and Well-being in Central Asia: The case of Kyrgyzstan" by German Institute for Economic Research DIW Berlin with collaboration of Center for Social and Economic Research, CASE-Kyrgyzstan. This survey is nationally representative and 
includes 3000 households, 8066 individuals and 40 communities sample. According to empirical estimation results the factors affecting the individual decision to migrate abroad the mostly related with household and community level characteristics rather than individual characteristics. Thus the age, marital status and education level of individual are not significant factors affecting the migration, while the gender and ethnicity are seen as significant factors. Precisely, women more actively migrating, hence the the difference is not so big, this is showing that external migration of Kyrgyzstan is gender balanced, and most migrating are Kyrgyz.

Consequently, the large scale of external migration in Kyrgyzstan has regional characteristics, and comes from communities and households with definite characteristics. These migration factors should be evaluated in the policy making in Kyrgyzstan. Thus migration is seen in the communities located near the country border, and where the lack of employment is exists. These are the main issues that should be dealed first. In these regions the employment and development program should be maintained in the short period. While the other important factors affecting the household characteristics. Here the composition of household is important. Hence migrants come from large household with labor force excess. These households should be taken into the special policy programs that could reduce migration outflow by subsidizing the potential migrants for actively taking labor participation in Kyrgyzstan. The other interesting result is that migrants mostly coming from urban areas, which is explained with internal migration from rural to urban areas before going abroad. This process should be regulated by settling informational offices in the remote areas, which could assist in acquiring the necessary information on save external migration, thus most migrants are engaged to migration with information taken from relatives or from those who have been abroad in their communities, by migration network.

\section{References}

- Ambrosini, J. W., \& Peri, G. (2012). The determinants and the selection of Mexico-US migrants. The World Economy, 35(2), 111-151.

- $\quad$ Balderas, J.U., Greenwood, M.J., (2010) "From Europe to the Americas: a comparative panel-data analysis of migration to Argentina, Brazil, and the United States, 1870-1910", Journal of population economics, 23:1301-1318

- Carlos, R. D. (2002). On the Determinants of International Migration in the Philippines: An Empirical Analysis1. International Migration Review, 36(1), 81-102.

- Constantinou, S. T., \& Diamantides, N. D. (1985). Modeling international migration: Determinants of emigration from Greece to the United States, 1820-1980. Annals of the Association of American Geographers, 75(3), 352-369.

- del Rey Poveda, A. (2007). Determinants and consequences of internal and international migration: The case of rural populations in the south of Veracruz, Mexico. Demographic Research, 16(10), 287-314.

- $\quad$ EDB Centre for Integration studies (2013) "Effects of accession of Kyrgyzstan into the CU and SES for labor market and human capital”, EDB: St. Petersburg

- Etzo, I., (2008) "Determinants of interregional migration in Italy: a panel data analysis", MPRA paper no.8637, http://mpra.ub.uni-muenchen.de/8637/

- GUAN, J., \& McElroy, J. L. (2012). The determinants of migration in small islands. Shima: The International Journal of Research into Island Cultures, 7(1), 80-95.)

- Karymshakov, K., Abdieva, R. \& Sulaimanova, B. (2014) "Determinants of international migration: The case of Kyrgyz Republic”, Вестник Кыргызского Национального Университета им.Ж.Баласагына

- Kim, K., \& Cohen, J. E. (2010). Determinants of International Migration Flows to and from Industrialized Countries: A Panel Data Approach Beyond Gravity1. International Migration Review, 44(4), 899-932.

- Lewer, J.J., Van den Berg, H., (2008) “A gravity model of immigration”, Economics letters, 99:1

- Mayda, M.A., (2010) "International migration: a panel data analysis of the determinants of bilateral flows", Journal of population economics, 23:1249-1274

- Olowa, O.W., Awoyemi, T.T., (2012) "Determinants of migration and remittances in rural Nigeria", Journal of development and agricultural economics, vol.4(7), pp.191-198

- Sulaimanova, B., \& Bostan, A. (2014). International Migration: A Panel Data Analysis of the Determinants of Emigration from Tajikistan and Kyrgyzstan. Eurasian Journal of Business and Economics, 7(13), 1-9.

- Sulaimanova, S. (2005). Labor Migration from the Kyrgyz Republic. Washington, DC: World Bank, unpublished report.

- World Bank Group (2016). Migration and Remittances Factbook 2016, Third Edition. Washington, DC: World Bank.

- $\quad$ Yang, X., \& Guo, F. (1999). Gender differences in determinants of temporary labor migration in China: A multilevel analysis. International Migration Review, 929-953. 
- Агаджанян, В., Кумсков, Г., Недолужко, Л. (2006). Демографические процессы в Кыргызстане. Журнал Демоскоп Weekly, №493-494. Январь 2012. http://demoscope.ru/weekly/2012/0493/analit02.php

- Демографический ежегодник Кыргызской Республики: 2010-2014.-Б: Нацстатком Кырг. Респ., 2015:$320 \mathrm{c}$

- Единый доклад по миграции в Кыргызской Республике, Государственная служба миграции при Правительстве Кыргызской Республики, Бишкек 2015

- Карымшаков К., Сулайманова, Б. (2015) “Экономическая ситуация в Российской Федерации и влияние на миграцию Кыргызстана”, отчет НИСИ

- Кумскова, Н.Х. (2015) «Внешняя миграция населения Кыргызской Республики», Вестник КРСУ. 2015. Том 15. № 8, стр 110

- Лукашова, И., Макенбаева, И., (2009) «Воздейтсвие мирового экономического кризиса на трудовую миграцию из Кыргызстана в Россию: качественный обзор и количественное исследование», Бишкек, $110 \mathrm{c}$

- Мамырканов, М., Элебаева, А., (2013) «Разработка Концепции миграционной политики Кыргызской Республики», Отчет НИСИ

- Мкртчян, Н., Сарыгулов, Б., (2011) «Международная миграция все больше ориентируется на Россию», Демоскоп Weekly, №481-482

- Муктарбек кызы, А., Сейитов, Ч., и Жениш, Н. (2015). Влияние денежных переводов на структуру расходов домохозяйств в Кыргызской Республике. Центр экономических исследований, НБКР, №2

- Омаров, Н., Махновский, В., «Миграционные процессы в Кыргызстане: современные тенденции и перспективы», Журнал «Центральная Азия и Кавказ», 1998 (13), http://www.cac.org/journal/131998/st_05_omarov.shtml - дата обращения 15/12/2015

- Отчет и рекомендации по Международной конференции «Передовой опыт в области защиты прав трудовых мигрантов и перспективы его применения в Кыргызстане», Тянь-Шаньский аналитический центр АУЦА, Бишкек, Кыргызстан, 3-4 июня 2013 года

- Сейитов, Ч.С., (2012) «Теоретические Аспекты Денежных Переводов», Сборник Научных Работ НБКР, ст. 45-56

- Сулайманова, Б. (2012) «Анализ влияния денежных переводов на рост ВВП с использованием систем одновременных эконометрических уравнений на примере Кыргызской Республики», журнал «Реформа», 3 (55), стр. 61-66

- Сулайманова, Б. (2011) «Влияние денежных переводов на ВВП Кыргызской Республики», журнал «Реформа»,1(53), стр.65-69, 2012

- $\quad$ Тары, Р. \& Сулайманова, Б. (2014) «Факторы, влияющие на эмиграционные процессы в Кыргызстане», Международный, научный, экономический журнал «Реформа» 